\title{
The Improbability of God - In the Perspective of E. V. Ramasamy
}

\author{
S. Gunasekar \\ Associate Professor, Department of Philosophy, National College, Tiruchirapalli-620001 (Affiliated to \\ Bharathidasan University, Tiruchirapalli) Tamilnadu, India.
}

\section{Introduction}

E.V.Ramasamy, popularly known as "Periyar" (the great man), was born at Erode town in Tamil Nadu, India, on $17^{\text {th }}$ September 1879. He started the Self-Respect Movement in 1925. The principles of Self-Respect Movement are against the irrational unscientific beliefs of the people. He insisted that the beliefs and practices of human beings should be subjected to justification. The thoughts that are incompatible to reason should be shelved. E.V.Ramasamy was bold enough to speak out explicitly and freely, without mincing words. He was not hesitant to tell the people that they were suffering, their lives were miserable only because of the unfair and unreasonable oppression to which they were being subjected to. To him, belief in god, religious faith, caste feelings, meaningless rituals and customs are irrational. On the contrary his views are based on legitimacy. He dislikes anything that is against reasoning.

E.V.Ramasamy rejected all superfluous and fallacious fact-claims no matter how prestigious the authority who holds them or how deeply one would personally like to believe them. E.V.Ramasamy without any fear vociferously expressed his views on the concepts of god, soul, the nature of man, religion, ethics, and education. To him, the ancient people conceived the idea of god to explain the meaning of wind, rain, sun and other phenomena. In India, the earth, mountains, air, fire, rivers, the sun the moon, rain, thunder, lightning and even certain diseases are deemed to be gods. They understood them as creations of god. Faith in the existence of god provided easy explanations for all phenomena and silenced the restless inquisitiveness of ignorant people. The belief in god remained because the codes of morals were based on it.

\section{The Significance Of The Study}

Superstition, religious fanaticism, irrational beliefs, supremacy of upper castes, untouchability and upholding of widowhood were all extensive in those days. There were most horrible forms of social hierarchical structure throughout the state in the name of god and religion. People were divided into number of castes. Almost all the members of working society were exploited. They were treated as untouchables. People belonging to the lowest caste amongst the Hindus of India, have continued to be uncared and unloved. These people were not only despised, ostracized and looked down upon, but also humiliated by the caste Hindus, and were being treated by them as untouchables. E.V.Ramasamy's mind was filled with annoyance and passion on seeing the discriminations in the name of god and religion. He considered all the prohibited activities such as aggression, denial of entry into the temples based on birth were a great injustice done to human beings. . He wanted that each one should have equal rights. This motivation of egalitarianism developed in his mind, embedded greater enormity and became a tireless commitment in him. His ardent desire was to bring equality, freedom and fraternity in the society by instilling rational thoughts. His untainted atheistic principles are objective and rational. The aim of this study is to propagate his atheism.

\section{The Concept of God Is Untenable}

Growth of scientific knowledge enabled to understand phenomena such as birth, consciousness, dream and death in a different way, which on the other hand needed no belief in god. After the advent of astronomy, we are aware of the rotation of earth, the journey of the sun and its reaching equinox, etc. When we were unable to find out the reason for solar and lunar eclipses we concocted a story of rahu and ketu, the snakes swallowing the sun and the moon respectively. Considering it to be a ceremonial contamination, people also took ritual bath and offered oblations. These notions were understandable when we had no knowledge of astronomy. Now we do not believe the story of a snake swallowing the sun or moon. Research in human anatomy and social hygiene has dispelled our notions of diseases. Those events that are unexplainable with cause and effect are said to be the actions of god. As man's knowledge grows in course of time, these notions are bound to disappear. It is 
true that what appears to be of divine power to one man does not seem to be so to another man. It is because of the difference in understanding and awareness that exists between one another.

E.V.Ramasamy emphasized that it is only man who uses the term god. The term god is not innate or impulsive. Parents introduced the term god to their children. There is a difference between the term god and other terms that taught by the parents to the children. Other terms denotes something. If we say this is a tree, we can show it to the child. But the term god has no denotation. It is only a habitual term. No one can show god to his child. It can be showed through imaginary photography or idols. The children heard the words very often from their parents or family members. If any child asked their parents immediately they replied that in this age you cannot understand it and when you grow you can understand it. ${ }^{1}$

\section{God Cannot Be Proved}

He vociferously declared that no single reasonable argument to believe the existence of god is there, but we have many reasons to disbelieve it. The cosmological proof also, like other proofs, can be disproved. According to this proof, whatever exists must have a cause or reason. This premise implies that god is the uncaused cause of the universe. It is obvious that the premise of the argument is contradicted by its conclusion. ${ }^{2}$

Therefore, god is the creation of mankind with their superstition. Most of the people believe god not because they have any valid reason but only because they have been trained to do so from their childhood. The arguments against the existence of god aim at showing that some particular conception of a god either is inherently meaningless, contradictory, or contradicts known scientific or historical facts, and that therefore a god thus described does not exist. Another argument held that the presence of evil in the world disproves the existence of any god, because any benevolent god would want to eliminate evil, and any omnipotent god would be able to do so. And, since there are unbelievers, either god does not exist or god does not influence mankind. Anyway, the existence of god is not proved. ${ }^{3}$

In his article published in the Journal Pakutharivu ${ }^{4}$, E.V.Ramasamy clearly mentioned that no theologian could convincingly explain what is meant by god. It is presumed therefore that every theologian clings dogmatically to what he calls god which is neither understandable to him nor explainable by him in detail.

Most of the people including theologians regret that they themselves are responsible for all their faults, bad qualities, poverty and sufferings and praying to god to get rid of those impediments. The Hindus fictitiously personates god and attribute a wife, children, a concubine, dress, food, a vehicle and a mansion to him as they attribute to human beings. Even Christians and Muslims do attribute good, bad, likes, dislikes and happiness to god. They have also imputed to him a quality of doing harm to those who do not pray and bless those who worship him and act according to his command.

He held that many theologians preached that god administers his providential rule only through human beings. Perhaps that is the reason why a beggar says that he got alms with the blessings of god. One who has secured a job says that he too got it because of the blessings of god. One who obtained some assistance from others too says the same thing. Even a man who gets himself relieved from a throng of people says that it is god who rescued him. If it is true, we cannot attribute responsibility to a man for all the good and bad occurrences. When god himself is omnipresent, keenly observing human thoughts and deeds, it is needless to pray to him. If god himself is solely responsible for both good and bad, we can see to it that there is no evil at all in the world.

An inherently benevolent god should not create poisonous insects, germs and viruses, deadly diseases, poverty, homicide, pillage, robbery, plunder cunningness, prostitution, serfdom, tyranny, felony and such evils. As different kinds of evil are always present in the world, we cannot accept the existence of a benevolent god.

The theist says that everything is done or actuated by god and without his knowledge nothing could take place. But in reality, man himself does everything. If a man falls sick, he goes to the doctor; but does not keep quiet thinking that his sickness is the act of god and it will be against god's wish if he seeks remedy. The theist says that god is omnipresent i.e., existing everywhere. But he goes to the temple to worship god. It is a repudiation of his own assertion of god's omnipresence. It is said that god is omnipresent, omnipotent and omniscient and he created the universe and controls the activities of mankind. E.V.Ramasamy replied that if we accept that there should be a creator for this universe, the question arises as to who created god. Further he questioned why god should create thieves, murderers, rogues, the sickly and some people rich and the vast majority as poor. He is responsible for all the miseries of the people. If it is so he could not be merciful. ${ }^{5}$

\section{The Concept Of God Is Only Introduced Not Inherited}

In his life time, E.V.Ramasamy for more than sixty years consistently expressed his opinion that there is no god and god is only a mere imagination of idiots. He opined that roughly three to five thousand years ago, reference about god must have been prevalent. Though man is keeping himself ready for further advancement and changes, the miserable fact is that in respect of god only, he keeps himself in a cocoon and proves to be a fool and an ignorant. Theists explain god as he is non-understandable, it goes far beyond one's thoughts and expressions, a mere belief that there is a god is itself a definition and none should ask definition about god and 
so on. No rationalist can accept this definition. An omnipotent god cannot be incomprehensible. There is no use of god either to this world or to the man. The very concept of god is a means of livelihood for the vested interest people.

When explaining the origin of the concept of god, E.V.Ramasamy uttered that the belief of god does not arise spontaneously in everybody at the time of one's own birth. It is not inherited. It is only introduced. In other words, it is taught. That is why we see the many number of gods with varied characteristics. Moreover, the believers do not have uniformity in their way of worship, nor is the god in one shape, one form, one name and so on. The belief in god is governed by the tenets of various religions, customs and manners. That is why god is different from one another. Christians hold one god, which is variant of the one prayed by Muslims. In Hinduism, Saivaites have a god which is different from that of Vaisnavaites. Apart from what they think of gods, even in their belief there are innumerable divisions. Those who are socially and financially advanced have got one god which is different from that of what the poor and illiterates pray. The reason for this difference is the very matter of god is circumstantial, seasonal, artificial and gradually inducted into the society at various stages.

E.V.Ramasamy opined that those who have taught about god must have been parents, teachers, religions and spiritual hymns. Whatever it is, belief in god was thrusted into society with a sole motive of obtaining or achieving blessings, benefits and comforts. Also a belief that one's own follies would be condoned or pardoned and also a greediness or ambition to get more than what one deserves. So belief in god is based on desires, ambitions and aspirations. The very concept is fallacious and a figment of imagination. It has no definite meaning at all. Because of this fact there arise innumerable interpretations on god. The god is not either preyed or wanted by any of the irrational creatures. If god himself has created in man, a love towards him, then he should create a similar love among other creatures that are irrational. In fact, had he been there, he should have done more for irrational creatures. That is why the rationalists say that the concept of god is only a characteristic shaped and made as places, languages and religions but not genuine, spontaneous and natural.

E.V.Ramasamy wanted that the innocent public must understand that the very concept of god is crafty device, fraudulent trickery and contemptible deceit. E.V.Ramasamy desired that the people themselves away from these and lead a plain rationalistic life. ${ }^{6}$ E.V.Ramasamy declared that destroy the god that calls you a sudra (the untouchable). Destroy the puranas (mythologies) and the ithihasas (epics) which give strength to Hindu god. Pray the god that is really kind, good, and intelligible, if any. ${ }^{7}$ But in Hinduism there is no god without the basis of mythologies and epics.

\section{There Is No God At All}

E.V.Ramasamy asserted that nobody has so far given any clear-cut meaning to god nor has anybody perceived it. It has been used to terrify the people and also to keep them in permanent obedience. On a close analysis of the belief of god, it is found that its definition not only vary but also contradictory and controversial. ${ }^{8}$

To drive away the imagery snags, he declared and made his followers pronounce boldly that,

"There is no god, there is no god, and there is no god at all.

He who invented god is a fool,

He who propagates god is a scoundrel,

He who worships god is a barbarian".

E.V.Ramasamy held that the people who believed in the existence of god are considered to be irrational. God is not a necessity for an intelligent man. God is not like food that is indispensable. It is only just like dress worn to suit the surroundings. That is the truth about god. If anyone is to say that the belief in god is absolutely necessary for life, such a person is merely a distilled dud or a log of wood. Moreover, such a person would not come forward to prove the existence of god to us. He will leave it to god himself to prove his existence. So, there is no denying the fact that god is the creation of fools. ${ }^{10}$

E.V.Ramasamy proclaimed that he who preaches god is a scoundrel. For, he has given a definite nature to god and attributed high qualities to him. Those who define god go on saying that god is omnipotent, omniscient and so on. They say that god has no shape and he is kind. Ignorant people could not say so. We can say that a person is ignorant, if he is unable to know a particular thing. But these people come forward to define and explain god. They intentionally dupe the people. When we ask a person how god looks like, he says that he is shapeless. One could not see a thing that has no shape. There are certain things which we can feel even though they have no definite shape. Senses of taste, smell, touch, sight and sound make us feel and infer from their impact. Similarly, though we cannot see the electricity we feel its functions. We realize it when we find its light or heat. It is absurd to believe a thing that we can neither see nor feel. He who wants us to believe must be a rogue. He who indulges in dishonest means can never be considered as honest. People are intentionally 
made idiots. By such roguish and dishonest means they want to defraud the people. So, he who propagates god is a scoundrel.

E.V.Ramasamy said that one who worships god is a barbarian. A barbarian does not think rationally. A barbarian has no reason, does not think, despite possessing thought and reason. One who worships god gives the go-by to his sense of reasoning and clings to blind faith. The conception about god was made in the age of barbarians. But the people continue to worship god even now without applying the test to what, why and how and by shutting their eyes and ears to the ever-growing scientific achievements of the present times which expose nature and its potentialities. Hence he declared that he who worships god is a barbarian. ${ }^{11}$

\section{Conclusion}

He expressed that the cause for caste discrimination, inequality, untouchability, superstition is religion. The causes for religion are puranas, sastras, smrtis, etc. The cause for puranas, sastras, smrtis, etc., is god. Therefore, the root cause for the deteriorated conditions of the depressed is god. Hence, god must be abolished. ${ }^{12}$

The philosophical outlook of E.V.Ramasamy on the concept of god reveals that his ideas arose out of his keen intellect and compassionate heart in the light of practical affairs. His thought process was the evolution of what he experienced with men and matters in day-to-day life, what he observed keenly around and what he came to know about the happenings in the world. The standpoints of E.V.Ramasamy on the concept of god instilled changes in the minds of the people by making them reflect introspectively.

\section{References}

[1] Singaravelu, Ma, Kadavulum Prapancamum, (Tamil Version), Periyar Suyamariyadhai Prachara Niruvana Veliyeedu, Chennai, 1997, p. 15

[2] Vetriyalagan, N., 100 Kealvigalukku Thanthai Periyarin Bathilgal, (Tamil version), Navamani Pathippagam, Pullambadi, 1996, p.30.

[3] Paguttharivaalar Kazhaga Kaiyedu, (Tamil version), Paguttharivaalar Kazhagam, Thanjavur, 1976, p.67.

[4] Palany Arangasamy (trans.), Periyar - Is There A God?, Emerald Publishers, 1996, p.5.

[5] Periyar - An Anthology, The Periyar Self-Respect Propaganda Institution, Madras, 1992, p.130.

[6] Palany Arangasamy (trans.), Periyar - Is There A God?, Emerald Publishers, 1996, p.13.

[7] Veeramani, K. Dr., (compiled by), Collected Works of Periyar E.V.R., The Periyar Self-Respect Propaganda Institution, Chennai, 2005, p.487.

[8] Thanthai Periyar, Thatthuva Vilakkam, (Tamil Version), Periyar Suyamariathai Prachara Niruvana Veliyeedu, Chennai, 1987, pp.16-20.

[9] Thavamani, M., Gods of Ingersoll, Shaw, Periyar, Russell, Emerald Publishers Rationalists' Forum, Chennai, 1997, p.65.

[10] Vetriyalagan, N., 100 Kealvigalukku Thanthai Periyarin Bathilgal, (Tamil version), Navamani Pathippagam, Pullambadi, 1996, p.31.

[11] Periyar - An Anthology, The Periyar Self-Respect Propaganda Institution, Madras, 1992, p.131.

[12] Vetriyalagan, N., 100 Kealvigalukku Thanthai Periyarin Bathilgal, (Tamil Version), Namani Pathippagam, Pullambadi, 1996, p.16. 